\title{
Community Knowledge Related to Mangrove Conservation Law Products
}

\author{
Eny Sulistyowati ${ }^{*}$, and Pudji Astuti ${ }^{2}$ \\ ${ }^{1}$ Faculty of Law and Social Sciences, State University of Surabaya, Surabaya, Indonesia
}

\begin{abstract}
Indonesia is a country that has an area of mangrove forests in the second place of the world. East Java is one of the provinces that have mangrove forests. The mangrove forest has various conditions, not only good conditions but also damaged conditions. The main cause of damage is the conversion of mangrove forests to ponds and the use of mangrove wood as charcoal. Mangrove forest has various functions so that the Indonesian government issues various laws and regulations relating to the preservation of mangrove forests. This study uses a qualitative approach. Data were collected by in-depth interviews and observations. The informants taken were people who lived around the mangrove area. The study location is on the north coast of East Java which includes Lamongan Regency, Gresik Regency, Pasuruan Regency, and Probolinggo Regency. The results of the study show that the majority of people know the mangrove conservation law products. Community knowledge is mainly obtained from the Village Head. Moreover, they do not know the types of law violations or types of law enforcement related to mangrove conservation. People living in mangrove areas know that there are regulations about mangrove forests, even though they do not know the substance.
\end{abstract}

\section{Introduction}

Indonesia has the second largest mangrove forest after Brazil. In 2011, mangrove forests were in good condition at $56.91 \%$, moderate at $10.69 \%$, bad at $7.20 \%$ and not identified at $25.20 \%$. The criteria for determining the condition of mangrove forests are based on "cover" and "density" of mangrove trees. Following are the standard criteria for mangrove damage.

Table 1.2 Standard Criteria for Mangrove Damage

\begin{tabular}{|l|l|l|l|}
\hline \multicolumn{2}{|c|}{ Criteria } & Cover (\%) & $\begin{array}{c}\text { Density of Tree / } \\
\text { Hectare }\end{array}$ \\
\hline \multirow{2}{*}{ Good } & Very Good & $\varepsilon 75 \%$ & $\varepsilon 1,500$ \\
\cline { 2 - 4 } & Medium & $\varepsilon 50 \%-\square 75 \%$ & $\varepsilon 1,000-\square 1,500$ \\
\hline Damaged & Rarely & $\square 50 \%$ & $\square 1,000$ \\
\hline
\end{tabular}

Source: Attachment I Decree of the Minister of Environment Life Number 201 of 2014

\footnotetext{
${ }^{*}$ Corresponding email : enysulistyowati@unesa.ac.id
} 
More than $90 \%$ of the damage to mangrove forests is caused by changes in land use [1]. One of the causes of damage is the change of land into ponds and the use of mangrove trees into charcoal. This condition affects the area of mangrove forests. Based on data from the Ministry of Maritime Affairs and Fisheries, in 2014 mangrove forests had an area of 4.4 million hectares and in 2015 decreased to 3.7 hectares [1].

Of course, this situation is worrying because mangrove forests have an important function for the environment. Mangrove forests have a variety of functions. This function is to protect from abrasion, barriers to land from the sea breeze, pollution protection and as a breeding ground for various kinds of fish [2]. Many types of fish that have a high economic value breed in mangrove areas. They can live in that place because of the various birds that stop by and throw away their feces. This affects fish production.

With the existence of various functions of the mangrove forest, the government seeks to protect mangrove forests. One of the government's efforts is to enact a set of laws and regulations. Some of these laws are the Law of the Republic of Indonesia Number 18 of 2013 concerning Prevention and Eradication of Forest Destruction and Law of the Republic of Indonesia Number 27 of 2007 concerning Management of Coastal Areas and Small Islands. One of the objectives of the regulation is to give severe sanctions for those who damage mangrove forests. Even so, there are still many members of the public damaging it. This study aims to identify community knowledge about legislation relating to mangrove forests.

\section{Methodology}

This study used a qualitative approach that produced descriptive data in the form of words and behavior was observed. Data collection techniques were observation and in-depth interviews. Research subjects were people who live in mangrove forest areas. The research locations included the north coast of Lamongan Regency, Gresik Regency, Pasuruan Regency, and Probolinggo Regency in East Java Province. The reason for the selection of the four regencies is the incessant development, including the construction of tourist attractions and industries and the processing of beach sand. The data obtained were analyzed qualitatively.

\section{Discussion}

Legal knowledge is one's knowledge of certain behaviors regulated by law. This knowledge is related to behavior that is prohibited and permitted by law. Legal knowledge has a relationship with the assumption that the public is considered to know the contents of the regulation when the regulation has been enacted. [1] This is not always true. The government has issued various laws and regulations relating to mangrove forests, although the community does not know its contents. Based on the results of interviews with people living in the mangrove forest area, the results show that the majority of people $(70.3 \%)$ know the laws and regulations regarding mangroves and $29.7 \%$ do not know.

The community obtains legal information regarding the mangrove forest from the village head at $33.6 \%$, from the regional apparatus at $10.2 \%$, from fellow community members at $9.4 \%$, from non-governmental organizations by $8.6 \%$, from the mass media by $7 \%$ and from the police by $1.6 \%$. Thus, the village head as the leader of the village community has an important role in socializing the legislation relating to mangrove conservation. 
The existence of legal socialization will make citizens have legal knowledge. Even so, it is expected that they also need to know the contents of the legislation relating to mangrove forests. People who have knowledge of legal content mean understanding the law. [2] In fact, people who do not know the types of violations in the legislation regarding mangroves can be interpreted as possible violations in the future. Communities who know the types of law violations related to mangrove forests are $75.8 \%$ and those who know about them are $24.2 \%$.

Community knowledge related to law enforcement in preserving mangrove forests is low. The people who have knowledge of law enforcement for the conservation of mangrove forests are only $16.4 \%$ and those who do not know are $83.6 \%$. Law enforcement is an effort to uphold the material law in order to create a prosperous society. [3] They know that the forms of law enforcement for mangrove forests are processed in court and there are decisions of $7 \%$, processed in court without a decision of $1.6 \%$ and prosecuted without a court process equal to $7.8 \%$.

\section{Conclusion}

From the explanation above it can be concluded that public knowledge of the existence of legislation is quite high. The village head has an important role as a socialization agent. In the future, the community is expected not only to have legal knowledge related to mangrove forests but also to have a legal understanding and legal attitude. If these three things are met, it is expected that community members have the behavior as ordered by laws and regulations relating to mangrove conservation.

\section{References}

1 CPM, Statistik Marine and Coastal Resources, (BPHN, Jakarta, 2017)

2 A. Carey, Sociology of Law. (LaksBang Pressindo Yogyakarta, 2017)

3 S. Mahmud, Indonesian Environmental Law Enforcement Enforcement of Administrative Law on Civil and Criminal Law Enforcement According to Law Number 32 of 2009 (Graha Ilmu, Yogyakarta, 2012)

2 G. M, A. S, G. A, and F. K, Eds., Designing Effective Management of Coastal and Small Marine Resources. Biak: USAID, 2013. 